some signal is needed to indicate that the eye has moved, but more precise information is not required.

We thank T. S. Collett and N. Graham for discussion. This work was supported by a grant from the MRC.

\section{P. LENNIE}

A. SIDWELL

Centre for Research on Perception and Cognition,

Laboratory of Experimental Psychology,

University of Sussex,

Brighton, UK

Received 15 June; accepted 18 September 1978.

1. MacKay, D. M. in Handbook of Sensory Physiology, Vol. 7/3 (ed. Jung, R.) 307-331 (Springer, Berlin, 1973).

2. Skavenski, A. A. \& Steinman, R. M. Vision Res. 10, 193-203 (1970).

3. Hallett, P. E. \& Lightstone, A. D. Vision Res. 16, 99-106, 107-114 (1976).

4. Westheimer, G. A.M.A. Archs Ophthal. 52, 710-724 (1954).

5. Finney, D. J. Probit Analysis (Cambridge University Press, London, 1971)

6. Monahan, J. S. Perception Psychophys. 12, 349-353 (1972).

6. Monahan, J. S. Perception Psychophys. 12, 349-353 (1972). 331-380 (Springer, Berlin, 1972).

8. Bridgeman, B., Hendry, D. \& Stark, L. Vision Res. 15, 719-722 (1975)

\section{Vanadate-stimulated natriuresis}

THE observation ${ }^{1-3}$ that $\mathrm{V}(\mathrm{v})$ is a potent inhibitor of $\left(\mathrm{Na}^{+}\right.$, $\mathrm{K}^{+}$)-activated renal ATPase raised the possibility that it has natriuretic and thus diuretic properties in the living animal. We report here experiments showing that it has.

Plastic catheters were placed in the urinary bladder and femoral vein of rats (250-350 g) under ether anaesthesia. While recovering from the anaesthetic, the animal was confined in a restraining box and placed on a laboratory balance. The opposite arm of the balance actuated the delivery of isotonic saline $(145 \mathrm{mM} \mathrm{NaCl}, 5 \mathrm{mM} \mathrm{KCl})$ from a peristaltic pump to the femoral vein, in such a way that, during the experiment, the urinary and evaporative losses were made good and the weight of the animal was maintained.

During the succeeding $2 \mathrm{~h}$ the rate of flow of urine became roughly constant. Sodium orthovanadate $(1.5 \mu \mathrm{mol})$ was then injected intravenously in $0.15-0.3 \mathrm{ml}$ of the same isotonic saline; these volumes are too small to affect urine flow by augmenting the plasma volume. Table 1 , which summarises the results of four consecutive experiments, shows the total excretion of water, sodium and potassium during the hours immediately preceding and immediately following the administration of vanadate. The flow of urine increased dramatically within a few minutes of the vanadate injection, reaching peak rates of about $1 \mathrm{ml} \mathrm{min}^{-1}$. As this represents approximately $50 \%$ of the glomerular filtration rate ${ }^{4}$, it is likely that vanadate acts, at least in part, on the proximal tubule. The sodium
Table 2 Distribution of ${ }^{48} \mathrm{~V} 75 \mathrm{~min}$ after the intravenous injection of $1.5 \mu \mathrm{mol}{ }^{48} \mathrm{~V}$-vanadate

\begin{tabular}{cccccc} 
Tissue & $\begin{array}{c}\text { Blood } \\
\text { plasma }\end{array}$ & $\begin{array}{c}\text { Renal } \\
\text { cortex }\end{array}$ & $\begin{array}{c}\text { Renal } \\
\text { outer } \\
\text { medulla }\end{array}$ & $\begin{array}{c}\text { Renal } \\
\text { papilla }\end{array}$ & Urine \\
${ }^{48}$ V content \\
$\begin{array}{l}\text { ( } \mu \text { mol per kg } \\
\text { wet weight) }\end{array}$ & 14.9 & 62.0 & 10.2 & 7.8 & 2.6 \\
\hline
\end{tabular}

concentration in the urine produced in response to vanadate approximated to that in plasma. The integrity of the nephrons was not lost, for neither glucose nor protein was detectable in any of the samples of urine. Also, the effect of vanadate seems to be reversible, as, in longer-term experiments, urine flow following a vanadate injection diminished after a few hours, but the kidney was still capable of responding to a further dose as it had before.

In the first of the experiments included in Table 1, we used ${ }^{48} \mathrm{~V}$-labelled vanadate and determined the distribution of tracer in the kidney and elsewhere $75 \mathrm{~min}$ after its administration, when the diuresis was still nearly maximal. Table 2 shows that ${ }^{48} \mathrm{~V}$ was selectively concentrated in the renal cortex. Otherwise, the distribution of radioactivity in the various organs was similar to that described by Hathcock et al. ${ }^{5}$. Within $75 \mathrm{~min}$ of the ${ }^{48} \mathrm{~V}$ injection, $43 \%$ of the radioactivity had been excreted.

We conclude that vanadate is a potent natriuretic and diuretic substance, perhaps the most potent now known. It remains to be determined (1) whether vanadate, at the naturally occurring blood or tissue levels, has a physiological role in controlling natriuresis, and (2) whether the natriuretic and diuretic effects of vanadate can be therapeutically useful.

J. J. C. is holder of a Macy Foundation Award.

\section{W. E. BALFOUR}

\section{J. J. GRANTHAM}

\section{M. GLYNN}

\section{Physiological Laboratory, \\ University of Cambridge, Cambridge, UK}

Received 30 June; accepted 14 September 1978.

\footnotetext{
1. Josephson, L. \& Cantley, L. C., Jr Biochemistry 16, 4572-4578 (1977)

2. Beaugé, L. A. \& Glynn, 1. M. Nature 272, 551-552 (1978).

3. Cantiey, L. C., Jr, Resh, M. D. \& Guidotti, G. Nature 272, 553-554 (1978).

4. Knight, T. F., Sonsom, S., Harok, L., Frankfurt, S. J. \& Weinman, E. J. Eur. J. Physiol. 373, 139-143 (1978).

5. Hathcock, J. N., Hill, C. H. \& Matrone, G. J. Nutr. 82, 106-110 (1968)

6. Mitchell, W. G. \& Floyd, E. P. Proc. Soc. exp. Biol. Med. 85, 206-208 (1954).
}

Table 1 Excretion of water, sodium and potassium before and after the intravenous injection of sodium orthovanadate

\begin{tabular}{|c|c|c|c|c|c|c|}
\hline \multirow[b]{2}{*}{ Experiment } & \multicolumn{3}{|c|}{ Excretion before injection } & \multicolumn{3}{|c|}{ Excretion after injection } \\
\hline & $\begin{array}{l}\text { Water } \\
\left(\mathrm{ml} \mathrm{h}^{-1}\right)\end{array}$ & $\begin{array}{c}\mathrm{Na} \\
\left(\mathrm{mEq} \mathrm{h}^{-1}\right)\end{array}$ & $\begin{array}{c}\mathrm{K} \\
\left(\mathrm{mEq} \mathrm{h}^{-1}\right)\end{array}$ & $\begin{array}{l}\text { Water* } \\
\left(\mathrm{ml} \mathrm{h}^{-1}\right)\end{array}$ & $\begin{array}{c}\mathrm{Na} \\
\left(\mathrm{mEq} \mathrm{h}^{-1}\right)\end{array}$ & $\underset{\left(\mathrm{mEq} \mathrm{h}^{-1}\right)}{\mathrm{K}}$ \\
\hline 1 & 5.22 & 0.598 & 0.325 & 49.6 & 7.05 & 0.442 \\
\hline 3 & 1.43 & 0.175 & 0.127 & 27.9 & 2.53 & 0.313 \\
\hline 4 & 2.10 & 0.220 & 0.197 & 28.5 & 3.91 & 0.301 \\
\hline Mean \pm s.e.m. & $2.57 \pm 0.90$ & $0.01 \pm 0.099$ & $0.299 \pm 0.043$ & $36.2 \pm 5.1$ & $4.84 \pm 1.07$ & $0.347 \pm 0.032$ \\
\hline
\end{tabular}

The dose, $1.5 \mu \mathrm{mol}$, was chosen arbitrarily as that which, if it were distributed uniformly in the body water, would give a concentration sufficient in vitro to cause $75 \%$ inhibition of $\left(\mathrm{Na}^{+}, \mathrm{K}^{\prime}\right)$ ATPase prepared from pig kidney. $1.5 \mu$ mol vanadate in a $300 \mathrm{~g}$ animal represents about $2.5 \%$ of the $L D_{70}$, determined in mice ${ }^{6}$; estimates of $L D_{100}$ suggest that vanadate is about equally toxic to rats and mice ${ }^{6}$.

* For comparison, it is worth noting that an equimolar dose of the therapeutic diuretic furosemide injected intravenously into a $300 \mathrm{~g}$ rat caused a diuresis averaging about $10 \mathrm{ml} \mathrm{h}^{-1}$ during the first hour, with peak flow rates up to about $0.3 \mathrm{ml} \mathrm{min}^{-1}$. 